

\title{
تقويم المناهج التربوية الحديثة وأثرها على مخرجات وزارة التربية - مائة
}

\author{
م. فرح خير الله فواز \\ قسم القانون العام \\ كلية القانون والعلوم السياسية \\ الجامعة العراقية العزية \\ العراق الم:اق
}

البريد الاككتروني: Farah_201184@yahoo.com

الملخص

أن المناهج التربوية تعتبر الركيزة الاساسية للعملية التعليمية التعلمية، حيث بها يتم الوصول الى الاهداف


التربية العر اقية فيتوجب خضوع المناهج الى عملية تقويمية مستمرة لمعرفة مدى فاعلية المناهج وهل يلبي المنهج الجديد منطلبات التعليم التي وضع لاجله، لذلك فقد تم اجراء هذا البحث باستخدام المنهج الوصفي الذي يهذف الى وصف الظواهر والاحداث باستخدام انموذج الجعفري للتقويم (1989) وتم توزيع استمارات الاستبيان لجمع المعلومات من قبل المدرسين و القائمين على تنفيذ المناهج وتم اجر اء تحليل احصائي للمعلومات الواردة للوصول الى النتائج المطلوبة للبحث، حيث ثم التوصل الى انه لا يوجد فروق ذات دلالة احصائية تبعا


المجال بينما احتل المحتوى المرتبة الاخيرة.

الكلمات المفتاحية: المناهج التربوية الحديثة، أنموذج الجعفري. 




\title{
Evaluating modern educational curricula and its impact on the outputs of the Ministry of Education
}

\author{
Lect. Farah Khairallah Fawaz \\ Public Law Department \\ Faculty of Law and Political Science \\ Iraqi University \\ Iraq \\ Email: Farah_201184@yahoo.com
}

\begin{abstract}
The educational curricula are the mainstay of the educational process, whereby the goals set by the Ministry for the educational process are reached, and due to the changes and developments based on the educational curricula by the Iraqi Ministry of Education, the curricula must be subject to a continuous evaluation process to determine the effectiveness of the curricula and whether the new curriculum meets the requirements The education for which he was set, Therefore, this research was conducted using the descriptive approach, which aims to describe phenomena and events using the Al-Jaafari Calendar Model (1989). Questionnaire forms were distributed to collect information by teachers and those in charge of implementing the curricula. A statistical analysis of the information received was conducted to reach the results required for the research. Where it was concluded that there are no statistically significant differences according to the gender variable, and by reviewing the percentage values, we find that teaching methods occupied the first rank among the paragraphs of the field, while the content ranked last.
\end{abstract}

Keywords: modern educational curricula, Al-Jaafari model. 




\section{الفصل الأول}












يؤدي عمليات متعددة نحو الموازنة و إصدار الأحكام و عمل الأشياء و الأقو ال وال و الأفعال.
















و الأنشطة أيضا.








المنهج أن يو اكب هذه التحديات بالتطوير و التجديد و التحسين.

مشكثة البحث:













لذللك ينبغي تقويم هذا المنهج ومر اقتبه بهدف تطويره من خلال تنقيح موضو عاتهاته وحذفها و إثرائها


أر ائهم في مجالات مختلفة للمناهج الإر اسية.




1- الإسهام في عملية تقويم المنهي فئه من حيث مراعاته للأهداف و المحتوى وطرائق التدريس والوسائل


2- إفادة الجهات المختصة من نتائج البحث وتعديل المنهج في ظل النتائج التي تم التوصل إليها. 




3-نزويد العاملين و المخططين في المناهج و التربوبين بالتغذية الراجعة.



يهدف البحث الحالي إلى تقويم المناهج الدراسية للمرحلة الثانوية في الجمهورية العراقية وفق أنموذج الجعفري (1989) المطور (2011)، للمجالات الآتية: 1- أهداف المنهج الدراسي. 2- 2- محتوى الكتب الدر اسية.


4- 3- الوسائل التعليمية. يتحدد البحث البحث:

1 المجالات المحددة في هدف البحث. 2- المناهج الدراسية المعتمدة في وزارة التربية والتعليم العر اقية للعام الدر اسي (2018- 2019).

1- - ما مدى تحقق أهداف المو اد الدراسية ومفرداتها في المناهج الدر اسية للمرحلة الثانوية. أسئلة البحث:




4- ما مدى تحقق فقر ات الوسائل التعليمية في المناهج الدر اسية للمرحلة الثانوية.



1- التقويم: هو عملية تتضمن إلإجة إصدار حكم على قيمة الثيء أو كميته في ضوء معيار أو محك من






التطوير و التحسين.(الثبلي،1984،صنئ122)

2- المنهج: هو مجموعة الخبرات التربوية، و الثقافية، والاجتماعبة، والفنية، التي تهيئها المدرسة


أو هو وثيقة تربوية مكتوبة تجسد مجمل المعارف والخبر ات.(الثبلي،1984،ص18)

3- الأنموذج: أنه تصور سابق للعملية التقويمية يشتمل الجو انب النظرية المتعلقة بمفاهيم التقويم



$$
\text { (226) محمد،1990) }
$$






الأنموذج في البحث الحالي لتقويم المنهج الدراسي.

5- المناهج الدراسية : هي المواد الدراسية التي وضعتها وزارة التربية والتعليم العراقية و التي طر أت عليها الكثير من التعديلات و التطوير التئ التيات خلال السنو ات السابقة. 




6- المرحلة الثانوية : يكون التعليم الثانوي عل مرحلتين متتابعتين (متوسط و اعدادي) مدة كل منهما



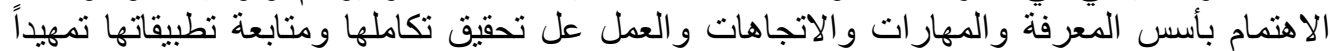
للمرحلة التالية أو للحياة العملية الانتاجية،



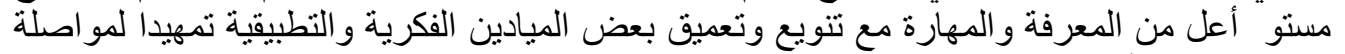
الدراسة العالية أو اعداده للحياة العملية الانتاجية.

\section{الفصل الثاني \\ الأدب النظري الفمل الناني \\ والدراسات السنابقة الفية}










ولتحديد مفهوم التقويم على نحو دقيق أنشار (عزيز) إلى إن هناك اتفاقا بين قسم من المربين عن التساؤلات الآتية: -كيف يطمئن المعلم إلى نجاحه في تحقيق الأهداف الموجودة في العملية التربوية؟




إن العملية التي يؤديها ألمعلم لمعرفة الإنهابة نحية عن هذه الأسئلة تسمى عملية التقويم.










ـالاستمرارية: بمعنى إن التقويم عملية زمانية مكانية وبما إن الزمان و المكان متجددان فإن الاستمرارية ضرورة حتمبة. ـالثمولية: أبي إن التقويم يجب أن يشمل الأهداف المرسومة وطر ائق التنفيذ ووسائله و أدو اته، بل طر ائق تقويك كل ذللك. ـالموضو عية: أبي تجاوز الأحكام القبلية أو الموقفية و عدم التأثر بذاتية المُقوم أو المقَوم.



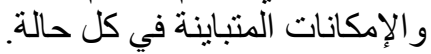


يتطلب تقويما لإصدار حكم جديد وقرار حديث. (الجعفري،1989) 




أنواع التقويم وأساليبه:

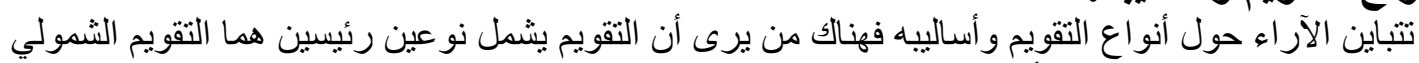

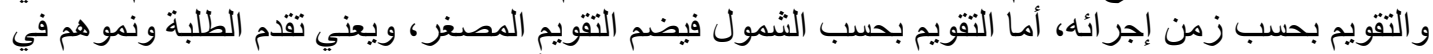

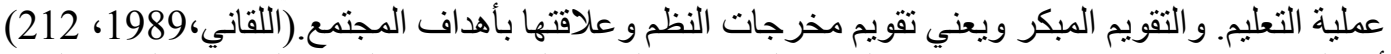

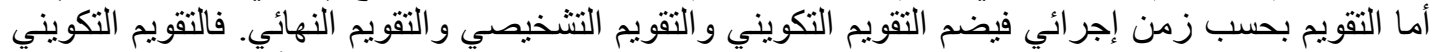
يهتم بالتشخيصات المحددة لنواحي القوة والضعف في النئ المنهج ويعطي تغذية راجعة في أثناء العملية التعليمية

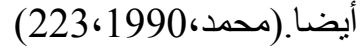
ويهتم التقويم التشخيصي بتعرف خصائص المتعلمين فبل البدء بتعلم مادة دراسية جديدة، أما التقويم النهائي

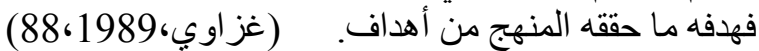

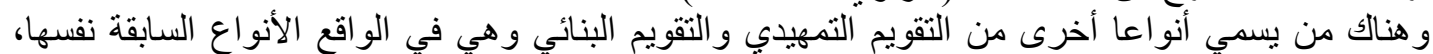

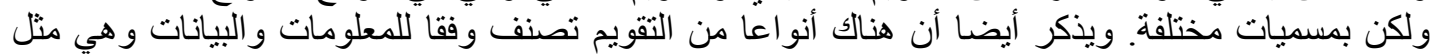
التقويم الكمي و التقويم النوعي.

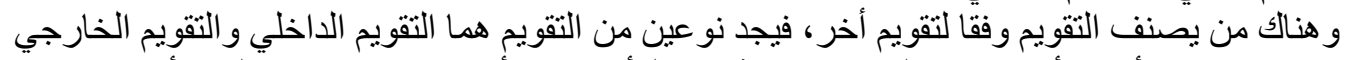

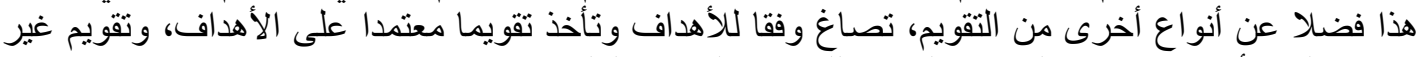

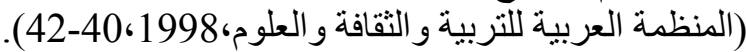


أما فيما يخص أساليب التقويم فإن الدراسات تكاد تتفق على وجود أساليب معينة للتقويم المدرسي ومن هذه





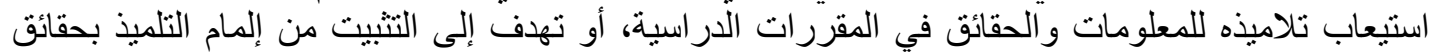

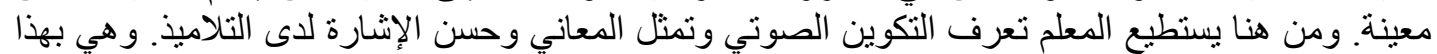

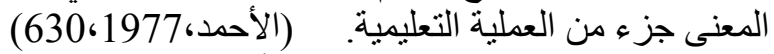

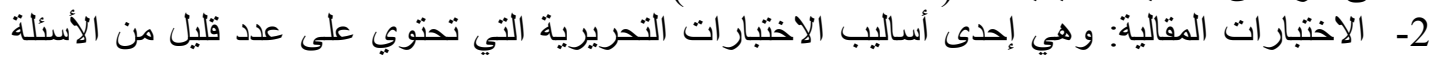

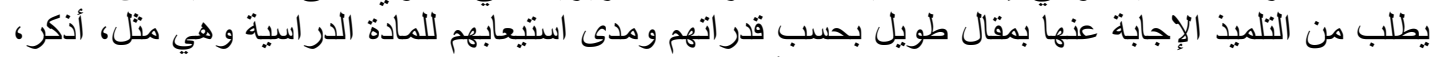

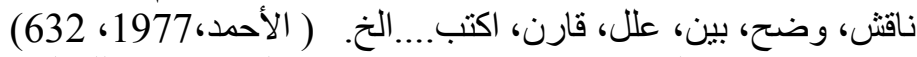

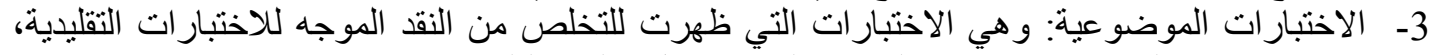



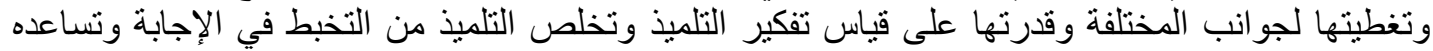

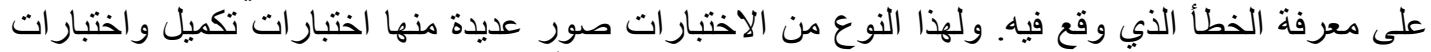



\section{نماذج التقويم}

لقد طور المهتمون بالمناهج وبنائها نماذج للتقويم. وسوف نعرض التمونم عدد من نماذج التقويم التي تستخدم في تقويم المناهج الدر اسية، ومن هذه النماذج:

\section{1- أنموذج تايلر للتقويم 1950:}

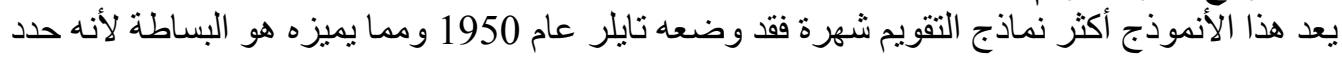

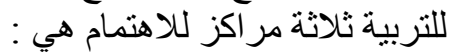

$$
\text { 1 - الأهداف التربوية. }
$$

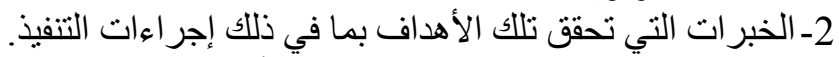

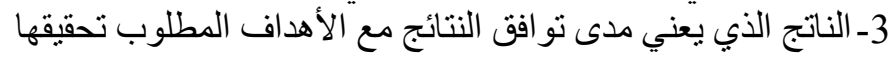



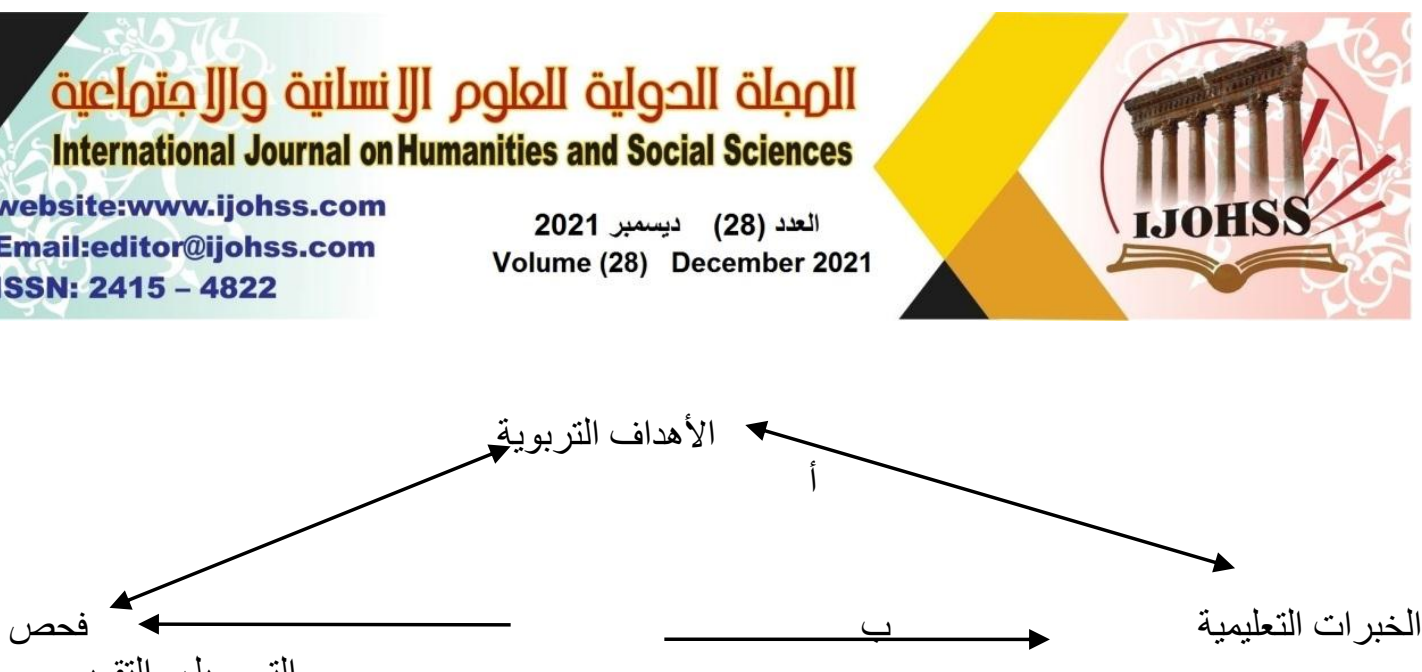

التحصبي و التقويم






الأهداف.

\section{2}

عرف برو فاس تقويم البرنامج أو المنهج بأنهائه عملية يتم فيها:

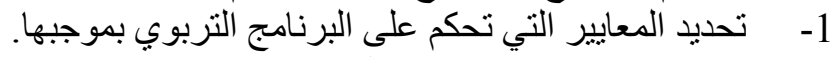

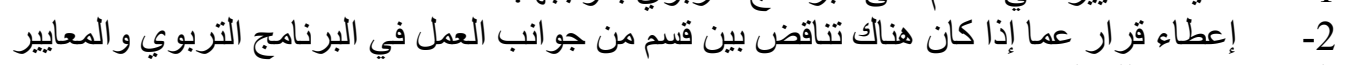
التي تتحكم في تلك الجو التباء

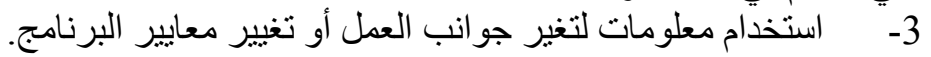



1 - التصميم: ويتم فيها تحديد طبيعة البرنامج و أهدافه ومستلزمات تطبيقها.

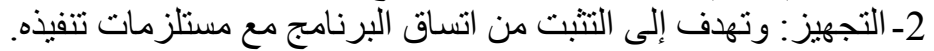

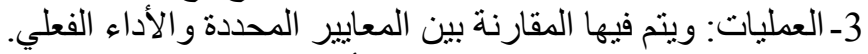



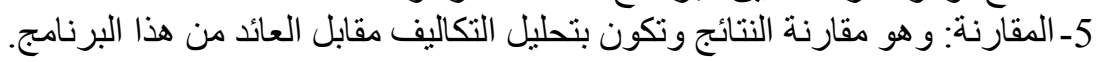

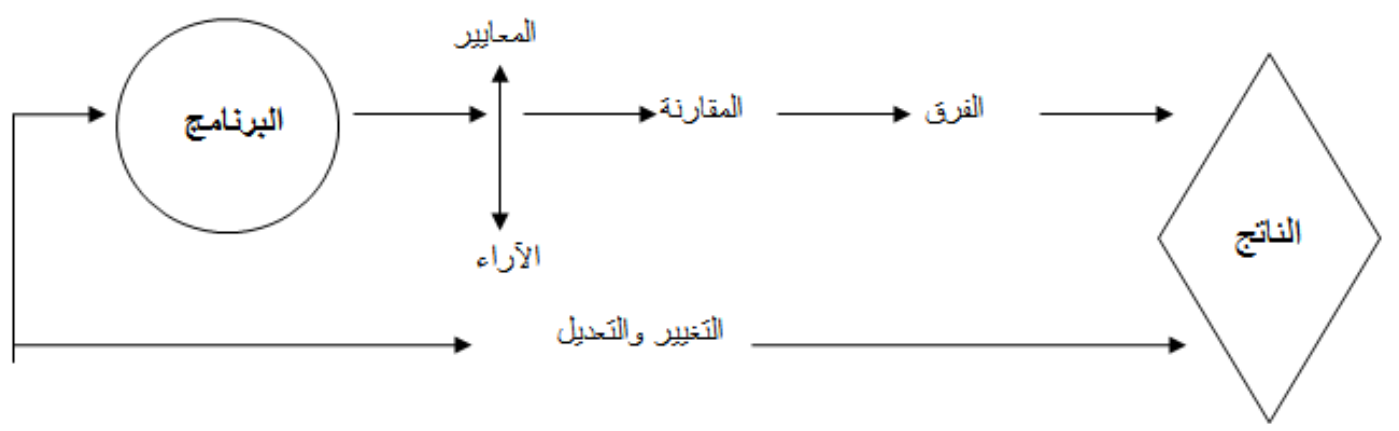




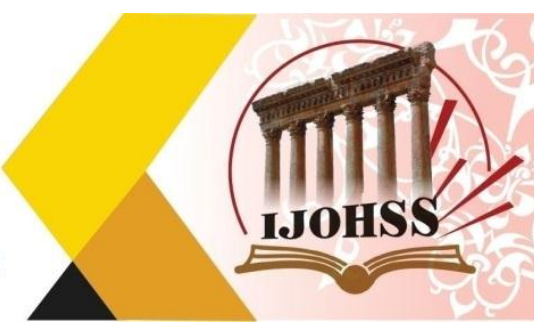

\section{3}

أعتمد الجعفري أنموذجا خاصنة لتقويم المناهج الدر اسية للتعليم العام في العر اق واعتئ التمد في البناء مفهوما خاصا

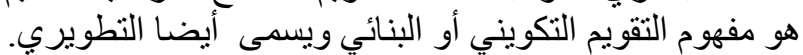

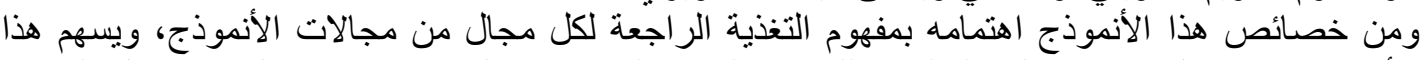



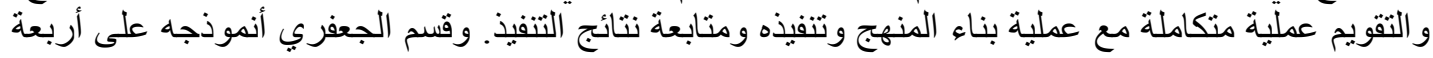

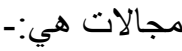

-مجال الأهداف التربوية العامة وأهداف المرادل. - مجال المو اد الدر اسية ومفرداتها. - مجال محتوى الكتب الدر اسية. -مجال النشاطات و الفعاليات المصاحبة.

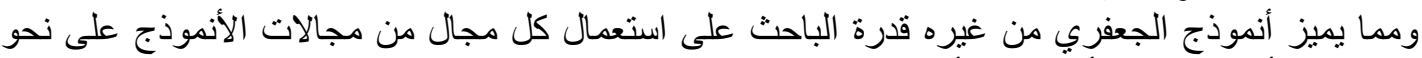
مفصل، وكأن هذا الجز أو أو المجال أنموذجا قائما بذاته.

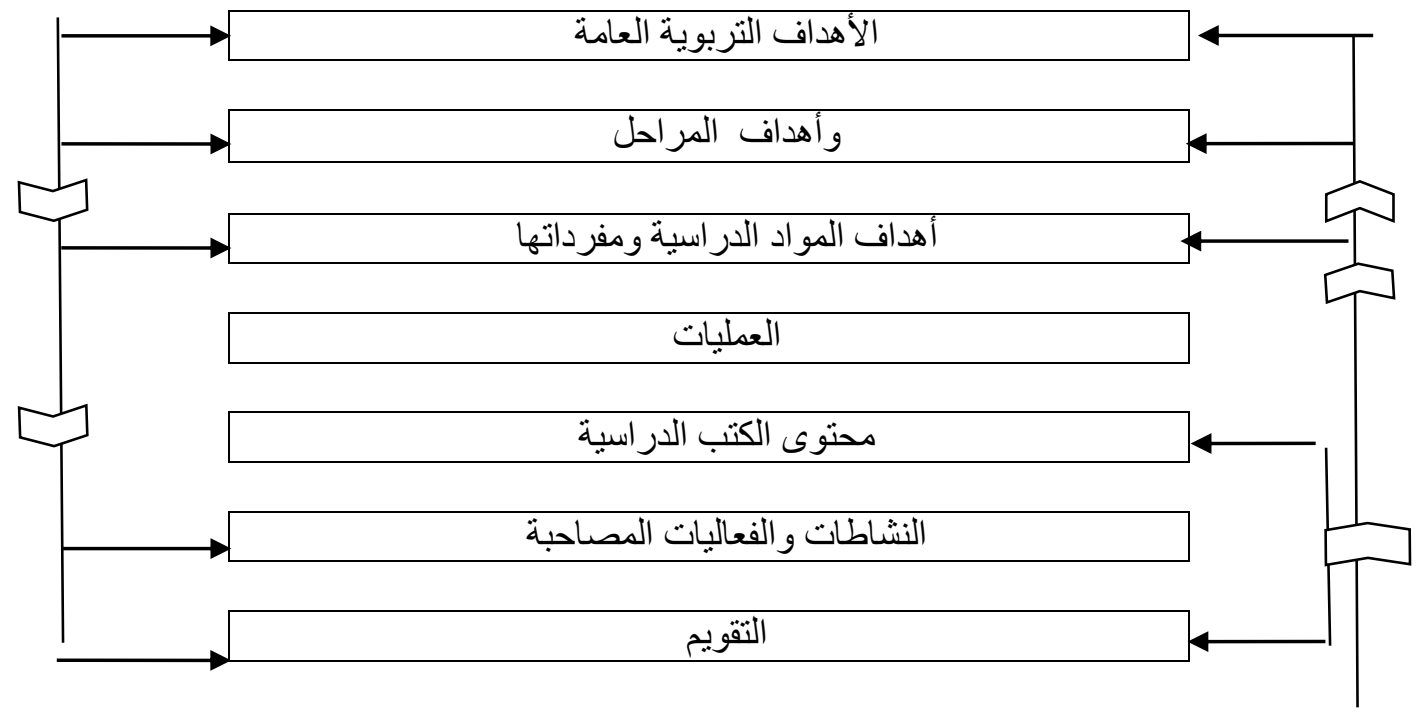

\section{4}

يعد أنموذج اللقاني أنموذجا للتقويم النهائي للمنهج، واهم ما أكده هذا الأنموذج هو در اسة الأهداف العامة للتربية



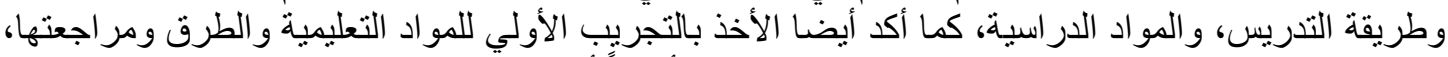

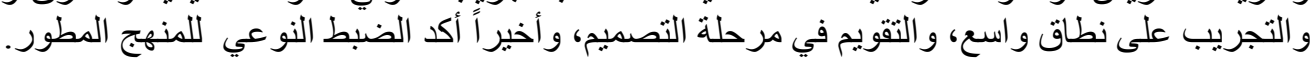





الار اسـات السابقة: - ابة 1 1979- دراسة الأشثمر (1979)





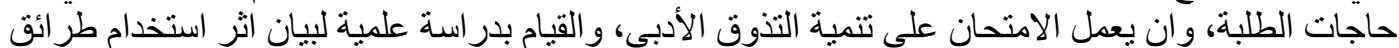

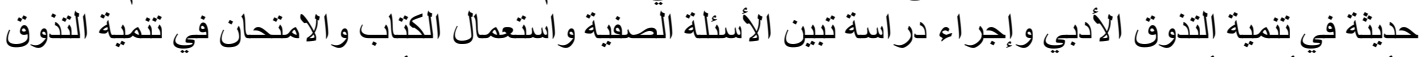



\section{2- د دراسة الصانع وآخرين (1981)}

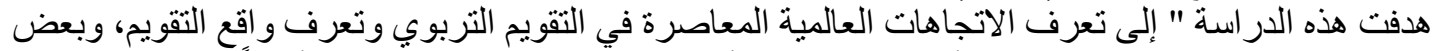

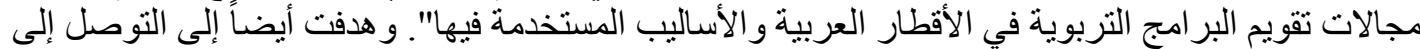

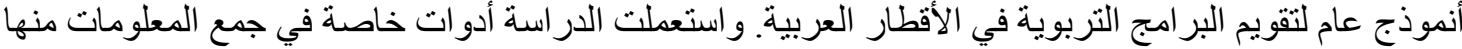

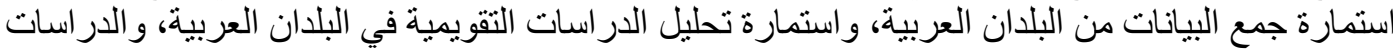
و البحوث في مجال التقويم التربوي.

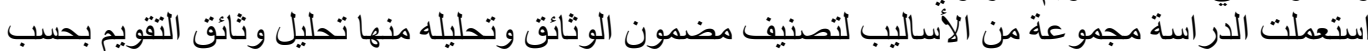
المجالات، وتحليل الوثائق بحسب منهجية الأنية التقو يم. توصلت الدر اسة إلى النتائج الآتية:

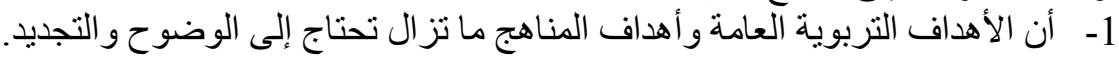

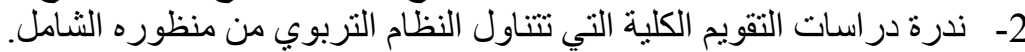
3- افتقار بحوث التقويم إلى المنهجية العامة.

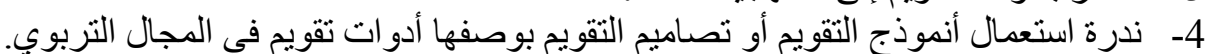
5- هنالك اتجاه حديث نحو التقويم الحديث و ونهجيته و أساليبه و أدو اته.

3- دراسة الجعفري(1989)

هدفت الدراسة "إلى بناء أنموذج لتقويم المناهج الدر اسية للتعليم العام في العر اق" مر اعيا العناصر الآتية:- 


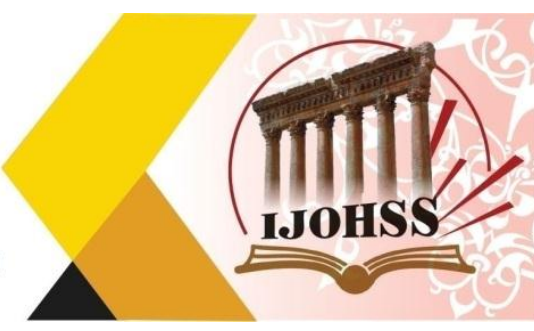

$$
\begin{aligned}
& \text { 1- الأهداف التربوية العامة، وأهداف المرحلة. }
\end{aligned}
$$

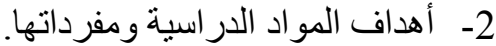

$$
\begin{aligned}
& \text { 3- - محتوى الكتب الدر اسية. } \\
& \text { 4- النشاطات و الفعاليات المصاحبة. } \\
& \text { وفي نهاية البحث وضع الباحث توطي توصيات أهمها: }
\end{aligned}
$$

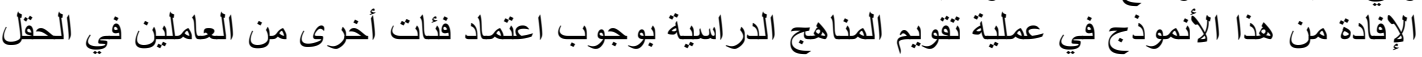

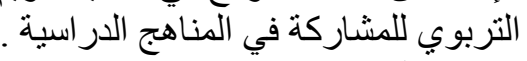

و اقتر ح الباحث مقترحات منها:

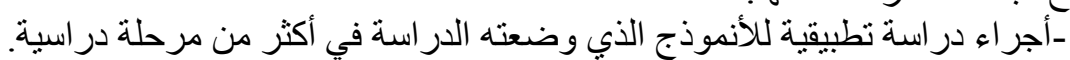
-بناء أنموذج لتقويم مناهج در اسية لمستو لنات الخيات أخرى من التعليم.

$$
\text { 4-دراسة إبر اهيم (1990) }
$$

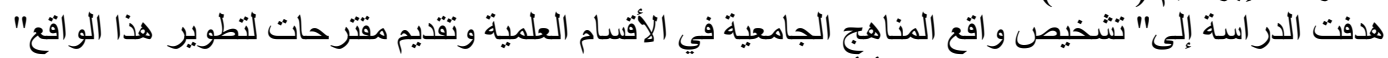

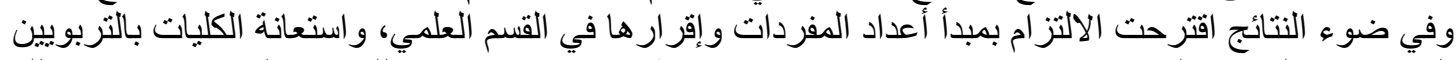

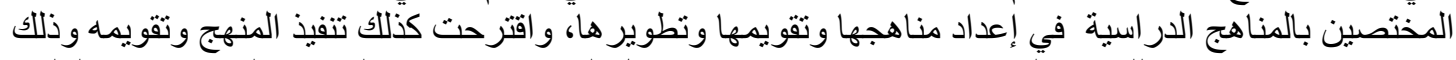

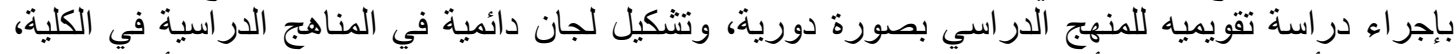

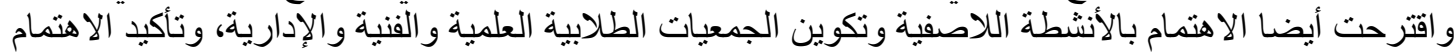
بالتدريب العلمي في المؤسسات الخدمية و الإنتاجية.

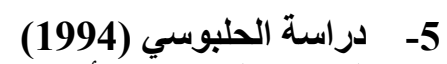

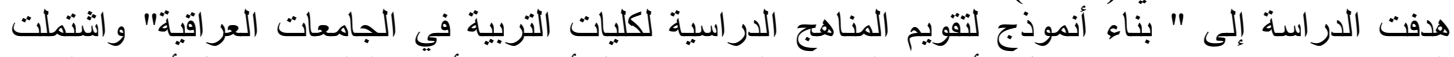

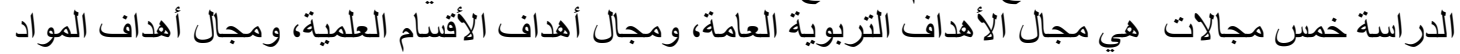

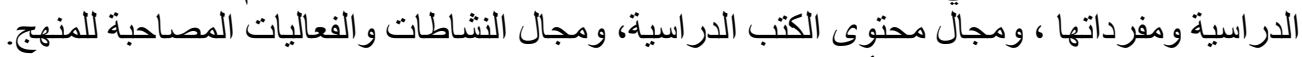
وتوصلت الدر اسة إلى نوصيات التوات أهمها:

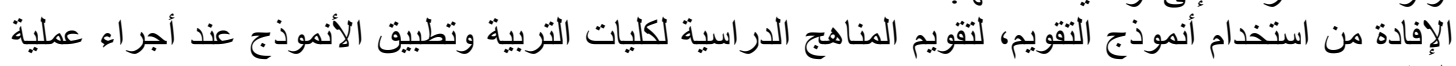
أما أهم المقترحات: بناء أنموذج لتقويم المناهج الدراسية في مجالات أخرى من مناهج التعليم العالي.

\section{الفصل الثالث

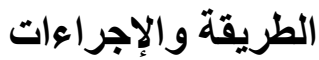

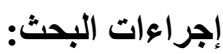

نستعرض في هذا الفصل الإجر اءات المتبعة لتحقيق هدف البحث وتسير هذه الإجر اءات على وفق ما يلي:-

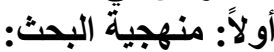

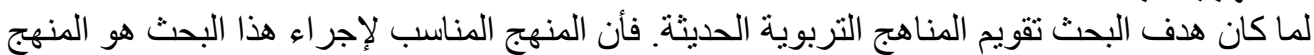

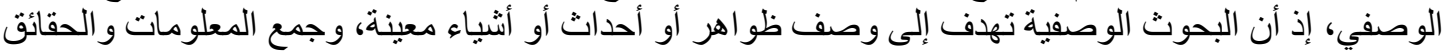

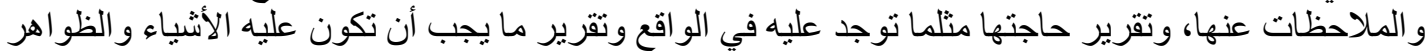

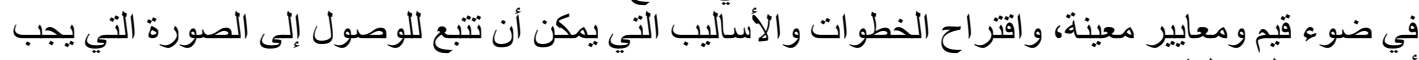

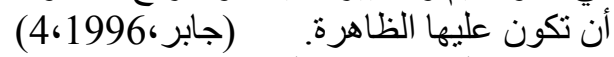

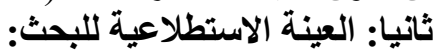

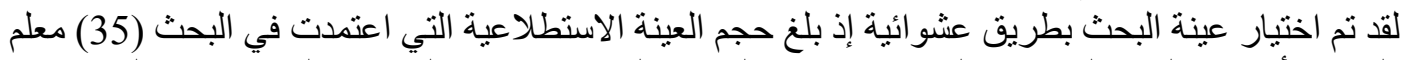

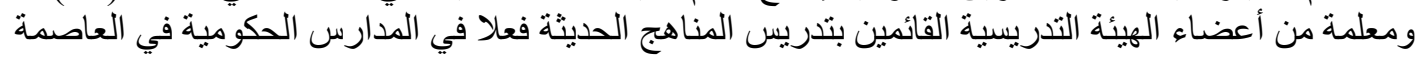




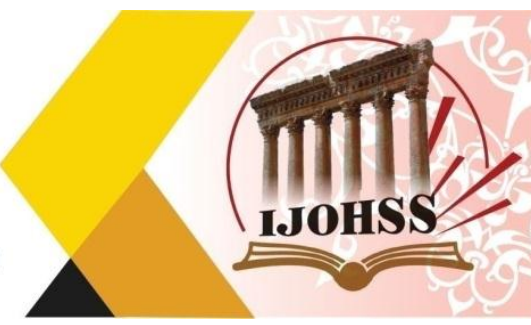

هدف البحث إلى تقويم المناهج التربوية الحديثة وقد أعتمد في هذا البحث على أنموذج الجعفري(1989)

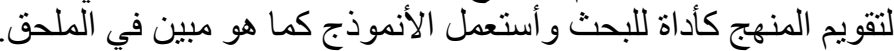
رابعا: الوسائل الإحصائية: أستعمل في البحث الحالي النظام الإحصائي(spss) للوصول إلى اللى النتائج الآتية:

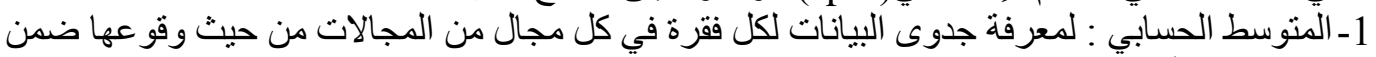
منطقة الرفض أو إبعادها عنها.

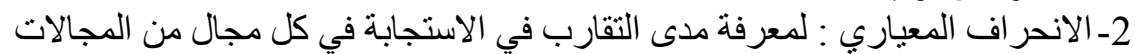

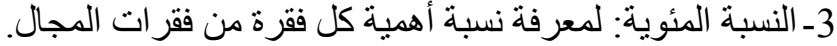

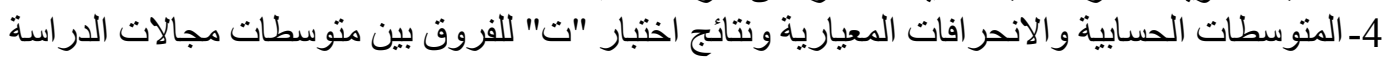

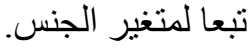

$$
\text { نتائج البحث وتفسير الرابعا }
$$

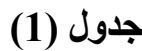

المتوسط الحسابي والانحراف المعياري والنسبة المئوية لمجال الأهداف.

\begin{tabular}{|c|c|c|c|c|c|}
\hline تيب & المئوية & الانحر افياري & المتوسط الحسابي & الفقرة & ت \\
\hline 1 & 82.29 & 0.68 & 4.11 & 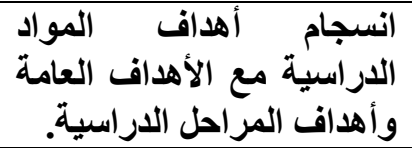 & 1 \\
\hline 17 & 72.57 & 0.91 & 3.63 & 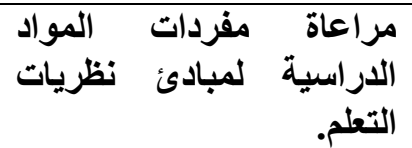 & 2 \\
\hline 2 & 78.29 & 0.85 & 3.91 & أهداف المواد الدراسية. تلى تجسيد & 3 \\
\hline 7 & 76.57 & 0.79 & 3.83 & وقوضة أهداف $\quad$ المفردات & \\
\hline 16 & 73.14 & 0.68 & 3.66 & الكامل ت مفرداتية فيما بينها. & 5 \\
\hline 13 & 74.29 & 0.75 & 3.71 & 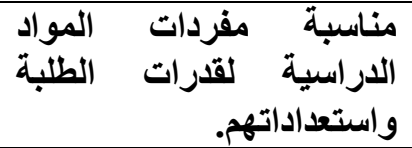 & 6 \\
\hline 20 & 66.29 & 0.96 & 3.31 & 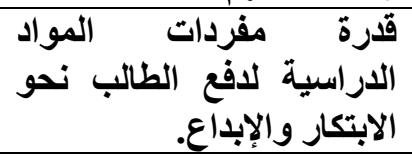 & 7 \\
\hline 19 & 66.86 & 1.06 & 3.34 & الطلبة وهواياتهم وتنميتها. عن الكثب & 8 \\
\hline 11 & 74.86 & 0.70 & 3.74 & إمكان ترجمة المفردات إلى & 9 \\
\hline
\end{tabular}

$$
\text { 35=ن }
$$


المجلة الحولية اللملوم الأسانية والإمتصاعية International Journal on Humanities and Social Sciences website:www.ijohss.com Email:editor@ijohss.com العدد (28) ديسمبر 2021 ISSN: 2415 - 4822

Volume (28) December 2021

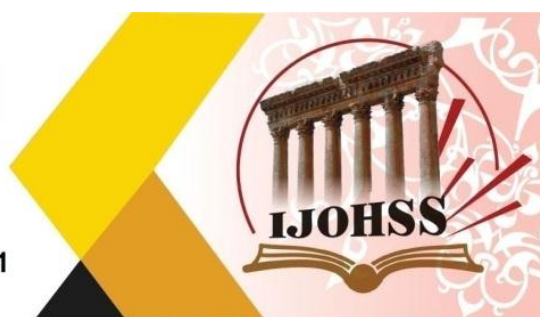

\begin{tabular}{|c|c|c|c|c|c|}
\hline & & & & خبرات ونثاطات تعليمية. & \\
\hline 8 & 76.00 & 0.63 & 3.80 & 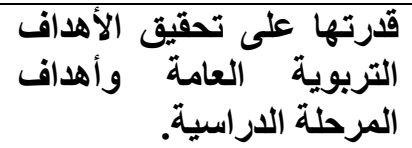 & $\begin{array}{l}\mathbf{1} \\
\mathbf{0}\end{array}$ \\
\hline 5 & 77.14 & 0.81 & 3.86 & 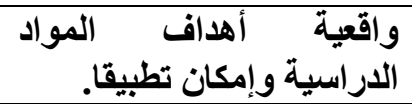 & $\begin{array}{l}1 \\
1\end{array}$ \\
\hline 14 & 73.71 & 0.72 & 3.69 & 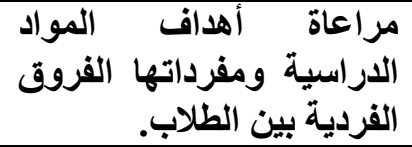 & $\begin{array}{l}1 \\
2\end{array}$ \\
\hline 12 & 74.86 & 0.82 & 3.74 & 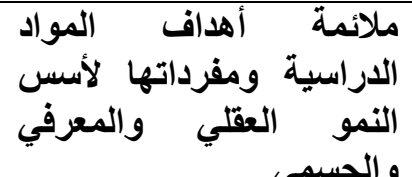 & $\begin{array}{l}1 \\
3\end{array}$ \\
\hline 6 & 77.14 & 0.77 & 3.86 & الدراسية بأهداف ألمدافلة المواد & $\begin{array}{l}1 \\
4\end{array}$ \\
\hline 9 & 76.00 & 0.58 & 3.80 & الدراسيتة فيما بينها. & $\begin{array}{l}1 \\
5\end{array}$ \\
\hline 18 & 72.00 & 0.95 & 3.60 & 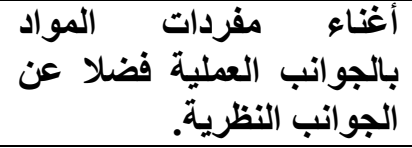 & $\begin{array}{l}1 \\
6\end{array}$ \\
\hline 10 & 75.43 & 0.81 & 3.77 & 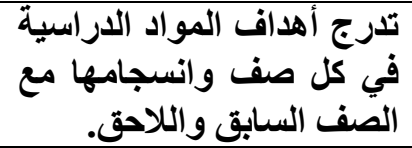 & 1 \\
\hline 3 & 77.71 & 0.80 & 3.89 & تلكامل أهداف المواد الدراسية & $\begin{array}{l}1 \\
8\end{array}$ \\
\hline 4 & 77.71 & 0.72 & 3.89 & 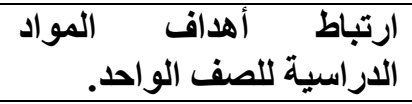 & $\begin{array}{l}1 \\
9\end{array}$ \\
\hline 15 & 73.71 & $\mathbf{0 . 8 0}$ & 3.69 & المادازن الدراسية. مفردات فصول & $\begin{array}{l}2 \\
\mathbf{0}\end{array}$ \\
\hline 21 & 76.57 & 0.75 & 3.83 & قوفرة أهداف المواد الدراسية & $\begin{array}{l}2 \\
1\end{array}$ \\
\hline & 74.91 & 0.53 & 3.75 & قالمحتيط بالطلبة. محاكاة الواقع & $\begin{array}{l}2 \\
2\end{array}$ \\
\hline
\end{tabular}

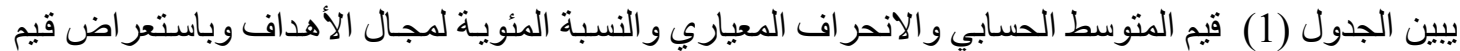

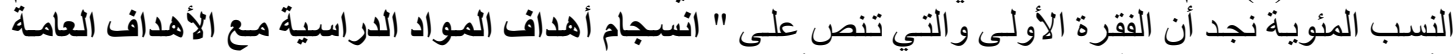

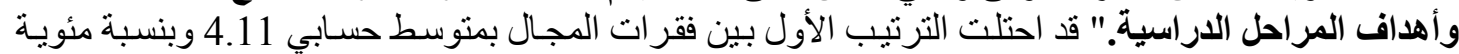

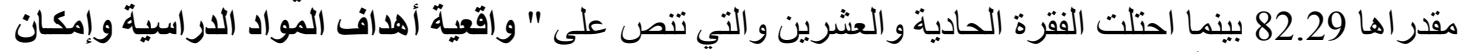

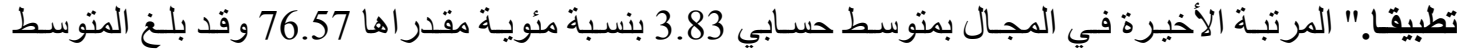
الحسابي لمهار ات التقويم 3.75 وبنسبة مئوية مقدر اها 74.91 الهئ 


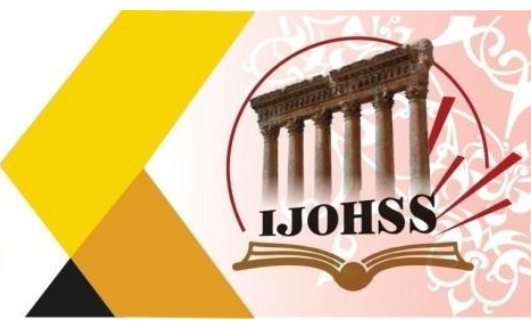

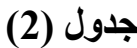

المتوسط الحسابي والانحر اف المعياري ولالنسبة المئوية لمجال المحتوى.

35=ن

\begin{tabular}{|c|c|c|c|c|c|}
\hline 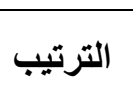 & 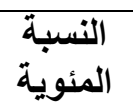 & 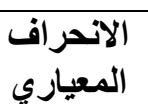 & المستوسط & 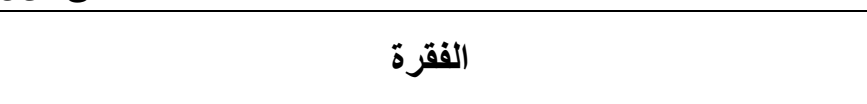 & $ت$ \\
\hline 19 & 70.29 & 0.92 & 3.51 & اشنتمالها على الوسائل التوضيحية والتريبات العملية. & 1 \\
\hline 21 & 68.57 & $\mathbf{0 . 8 5}$ & 3.43 & قدرتها على تهيئة الفرص لتطوير أنماط من التفكير. & 2 \\
\hline 6 & 76.00 & 0.72 & 3.80 & قارتها على تهيئة الأجواء لغرس اتجاهات مرغوبا فيها لدى & 3 \\
\hline 8 & 74.86 & 0.70 & 3.74 & تعزيزها بالصور والأثكال التوضيحية. & 4 \\
\hline 2 & 78.29 & 0.56 & 3.91 & تعبيرها عن أهداف المرحلة التعليمية. & 5 \\
\hline 1 & 81.71 & 0.78 & 4.09 & تعبير المحتوى عن أهداف المادة الدراسية المؤلف من أجلها. & 6 \\
\hline 3 & 78.29 & $\mathbf{0 . 7 0}$ & 3.91 & سلامة لغة المحتوى وبساطتها. & 7 \\
\hline 12 & 73.71 & $\mathbf{0 . 8 0}$ & 3.69 & أصالة القيم التي يتضمنها المحتوى ومعاصرتها. & 8 \\
\hline 10 & 74.29 & 0.79 & 3.71 & مراعاة تنظيم المحتوى للأسس النفسية والتريوية. & 9 \\
\hline 15 & 71.43 & 0.81 & 3.57 & كفاية الأسئلة المتضمنة في المحتوى وتنوعها. & 10 \\
\hline 11 & 74.29 & 0.79 & 3.71 & وخبرات واتجاهات. العلمية والحداثة فيما يطرحه المحتوى من معارف & 11 \\
\hline 5 & 77.14 & 0.69 & 3.86 & مراعاة المحتوى للفروق الفردية بين الطلبة. & 12 \\
\hline 7 & 76.00 & 0.76 & 3.80 & ارتباطه بالبيئة الاجتماعية للطلبة. & 13 \\
\hline 16 & 71.43 & $\mathbf{0 . 8 5}$ & 3.57 & ارتباطه بالبيئة الطبيعية للطلبة. & 14 \\
\hline 17 & 70.86 & 0.92 & 3.54 & تضمنها المحتوى. التسلسل المنطقي في عرض المعلومات والأفكار التي & 15 \\
\hline 18 & 70.86 & 0.74 & 3.54 & قدرته على تنمية مهارات عقلية وعلمية وعملية. & 16 \\
\hline 4 & 77.71 & 0.83 & 3.89 & قالأردافه على خلق الفرص لممارسة أنماط السلوك المتضمنة & 17 \\
\hline 22 & 68.57 & 0.78 & 3.43 & جودة الطباعة والإخراج للكتاب. & 18 \\
\hline 13 & 72.57 & $\mathbf{0 . 8 8}$ & 3.63 & مراعاة عنصر التشويق في إعداد المحتوى. & 19 \\
\hline 24 & 66.86 & 1.06 & 3.34 & خلو المحتوى من الحشو والتكرار. & 20 \\
\hline 25 & 64.57 & 0.91 & 3.23 & مناسبة مادة الكتاب للسـاعات المخصصة له. & 21 \\
\hline 14 & 72.00 & 0.77 & 3.60 & قارة المحتوى على فسح المجال لنشاطات وفعاليات مضافة. & 22 \\
\hline 23 & 67.43 & 0.84 & 3.37 & التوازن بين فصول الكتاب. & 23 \\
\hline 9 & 74.86 & 0.74 & 3.74 & التمهيد للكتاب بمنظومة تثير رغبات الطلبة نحو المحتوى. & 24 \\
\hline \multirow[t]{2}{*}{20} & 69.71 & 1.04 & 3.49 & ربط مجالات المعرفة بعضها ببعض. & 25 \\
\hline & 72.89 & 0.51 & 3.64 & 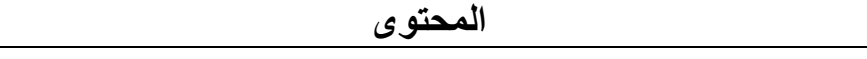 & \\
\hline
\end{tabular}

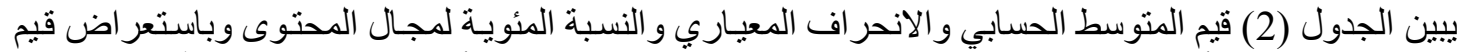

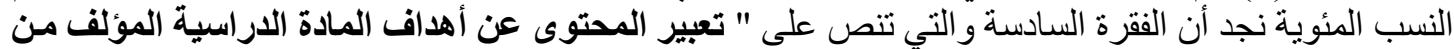
أجلها." قد احتلت الترتيب الأول بين فقرات المجال بمنوسط حسابي 4.09 وبنسبة مئويـة مقدر الها 81.71 بينما 


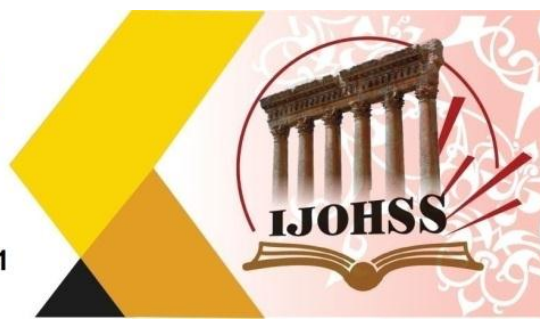

احتلت الفقرة الحاديـة و العشرين و التي تنص على " مناسبة مـادة الكتـاب للسـاعات المخصصـة لـه. " المرتبـة الأخيرة في المجال بمتوسط حسابي 3.23 بنسبة مئوية مقدر الها وقد بلغ المتوسط الحسابي لمهار الت التئن التقويم 3.64 وبنسبة مئوية مقدر اهـا ت و

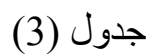

المنوسط الحسابي و الانحر اف المعياري والنسبة المئوية لمجال الوسائل التعليمية. 35=ن

\begin{tabular}{|c|c|c|c|c|c|}
\hline الترتيب & المئوية النسبة & الانحرياري & الحستوسطي & 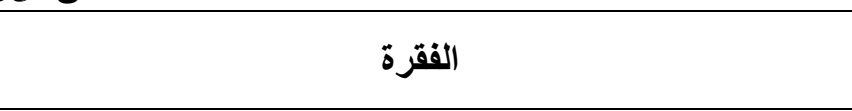 & $ت$ \\
\hline 8 & 74.29 & 0.86 & 3.71 & احتوائها التنوع، السمعية، البصرية، والسمعية والبصرية. & 1 \\
\hline 3 & 76.00 & 0.76 & 3.80 & مناسبتها للمواقَف التعليمية. & 2 \\
\hline 6 & 74.86 & 0.92 & 3.74 & جاذبيتها ووضوحها. & 3 \\
\hline 5 & 75.43 & 0.69 & 3.77 & إسهامها في تحقيق فهم التلاميذ. & 4 \\
\hline 7 & 74.86 & 0.85 & 3.74 & إسهامها في جذب انتباه التلاميذ وفقا للقدرات والاستعدادات. & 5 \\
\hline 12 & 73.14 & 0.87 & 3.66 & مساعدتها على توفير خبرات مضافة. & 6 \\
\hline 13 & 72.57 & 0.73 & 3.63 & أن يتعلهـا فرص التلاميذ للتوصل إلى المعرفة والمهارات المطلوبة & 7 \\
\hline 1 & 78.29 & 0.70 & 3.91 & انتمائها إلى اللهذف التعليمي. & 8 \\
\hline 9 & 73.71 & 0.90 & 3.69 & مناسبتها لمستوى التلاميذ. & 9 \\
\hline 15 & 70.29 & 0.85 & 3.51 & مراعاتها للخصائص الفنية. & 10 \\
\hline 16 & 69.71 & 0.78 & 3.49 & مناسبتها لزمن الحصة الاراسية عند عرضها. & 11 \\
\hline 14 & 72.57 & 0.77 & 3.63 & حداثتها ومواكبتها للتطور العلمي والتقني. & 12 \\
\hline 2 & 77.71 & 0.76 & 3.89 & وضوحها الشكلي واللغوي. & 13 \\
\hline 10 & 73.71 & 0.87 & 3.69 & مناسبتها لعدد الدارسين. & 14 \\
\hline 4 & 76.00 & $\mathbf{0 . 8 0}$ & 3.80 & بساطتها وتر ابط معلوماتها. & 15 \\
\hline \multirow[t]{2}{*}{11} & 73.71 & $\mathbf{0 . 8 0}$ & 3.69 & إثارتها للتساؤلات والنقاش. & 16 \\
\hline & 74.18 & 0.63 & 3.71 & الوسبائل التعليمية & \\
\hline
\end{tabular}

يبين الجدول (3)

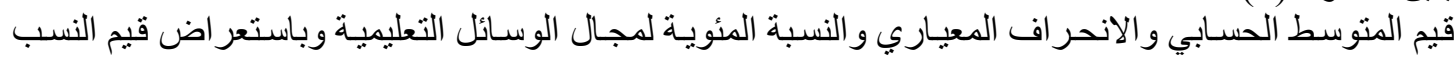

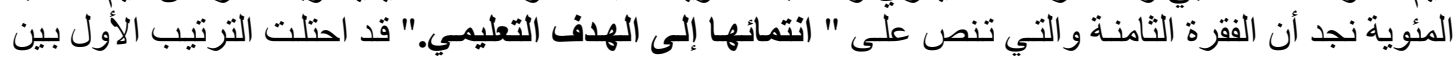
فقر ات المجال بمتوسط حسابي 3.91 وبنسبة مئوية مقدر الها

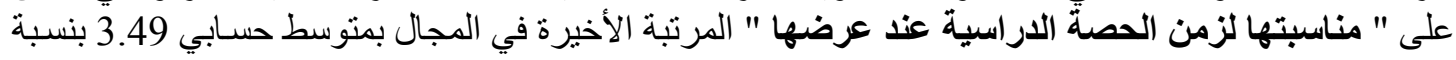




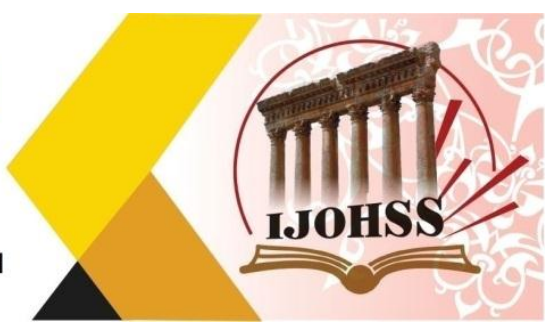

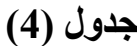

المتوسط الحسابي والاتحراف المعياري والنسبة المئوية لمجال طرائق التدريس.

35=ن

\begin{tabular}{|c|c|c|c|c|c|}
\hline 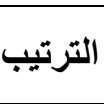 & المئوية & الالتحراف & الحستوسط & 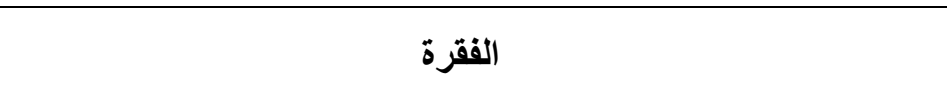 & 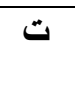 \\
\hline 1 & $\mathbf{8 0 . 0 0}$ & 0.64 & 4.00 & إمكانيتها في تحقيق الأهداف التعليمية. & 1 \\
\hline 6 & 74.29 & 0.86 & 3.71 & مراعاتها لمستوى الطلبة (النفسي والجسمي والاجتماعي). & 2 \\
\hline 4 & 76.00 & 0.72 & 3.80 & مناسبتها لطبيعة المادة الدراسية"الموضوع الدراسي". & 3 \\
\hline 11 & 72.57 & 0.73 & 3.63 & مراعاتها للفروق الفردية بين الطلبة. & 4 \\
\hline 7 & 73.71 & 0.83 & 3.69 & قرتها على إثثارة اهتمام المتعلم ود|فعيته الايجابية. & 5 \\
\hline 5 & 74.86 & 0.82 & 3.74 & إتاحتها فرص المشاركة الفاعلة للطلبة. & 6 \\
\hline 15 & 69.14 & 0.66 & 3.46 & تمكنها من توظيف الموضوع الدراسي وربطها بحياة الطلبة وخبراتهر. & 7 \\
\hline 16 & 66.86 & 0.73 & 3.34 & إتاحتها فرص العمل الجماعي التعاوني على أسس ديمقراطية. & 8 \\
\hline 13 & 69.71 & 0.89 & 3.49 & قُرتها على تنمية الثجاعة الَفكرية عند الطلبة. & 9 \\
\hline 7 & 73.71 & 0.68 & 3.69 & قدرتها على إثارة السؤال والتساؤل والتعبير عن الرأي. & 10 \\
\hline 10 & 73.14 & 0.76 & 3.66 & مناسبتها للمرحلة التعليمية. & 11 \\
\hline 1 & 80.00 & 0.77 & 4.00 & تنوعها وفق الموضوع الدراسي. & 12 \\
\hline 13 & 69.71 & $\mathbf{0 . 8 5}$ & 3.49 & مناسبتها لعدد طلاب الصف. & 13 \\
\hline 12 & 70.29 & 0.78 & 3.51 & تو افقها مع أغراض التعليم داخل الصف وخارجه. & 14 \\
\hline 7 & 73.71 & 0.76 & 3.69 & مناسبتها لإمكانات المدرسة. & 15 \\
\hline 3 & 77.14 & $\mathbf{0 . 8 5}$ & 3.86 & إمكانيتها في تحقيق الأهداف التعليمية. & 16 \\
\hline & 78.43 & 0.60 & 3.92 & طرائق التدريس & \\
\hline
\end{tabular}

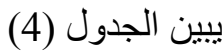

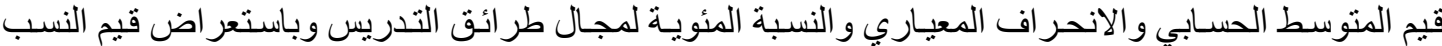

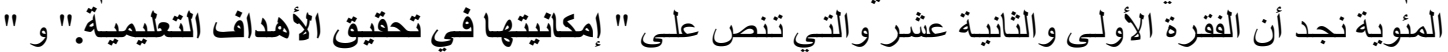

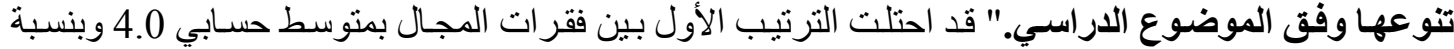

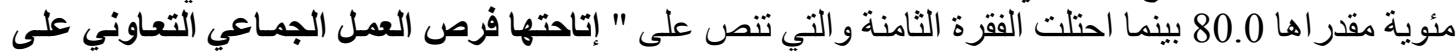

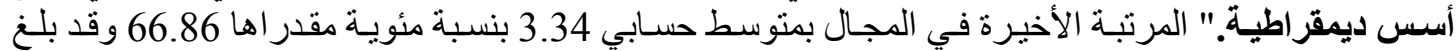
المتوسط الحسابي لمهار ات التقويم 3.92. 


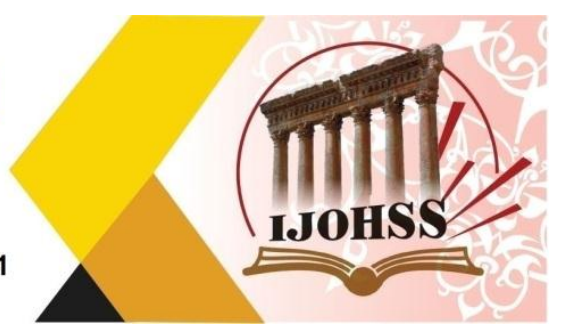

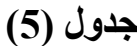

المتوسط الحسابي والانحراف المعياري والنسبة المئوية للاراسة

35=ن

\begin{tabular}{|c|c|c|c|c|}
\hline الترتيب & النسبة المئوية & الالتحراف & الحستوسط & \\
\hline 2 & 74.91 & 0.53 & 3.75 & الأهداف \\
\hline 4 & 72.89 & 0.51 & 3.64 & المحتوى \\
\hline 3 & 74.18 & 0.63 & 3.71 & الوسائل التعليمية \\
\hline 1 & 78.43 & 0.60 & 3.92 & طرائق التّريس \\
\hline & 75.10 & 0.53 & 3.76 & الكلي \\
\hline
\end{tabular}

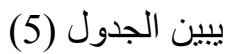

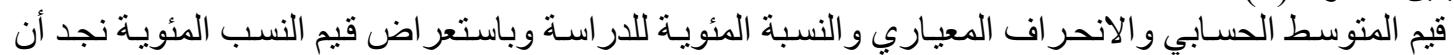

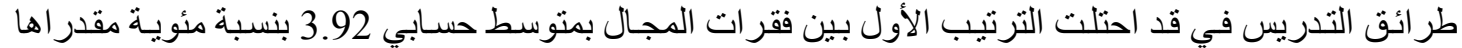
78.43 بينما احتل مجال المحتوى في المرتبة الأخيرة في المجال بمتوسط حسـابي 3.64 بنسبة مئويـة مقدر اها

72.89

وقد بلغ المتوسط الحسابي للار اسة 3.76

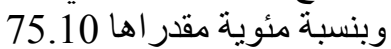

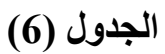

المتوسطات الحسابية والانحر افات المعيارية ونتائج اختبار "ت" للفروق بين متوسطات مجالات الدر اسة تبعاً لمتفير الجنس انتس

\begin{tabular}{|c|c|c|c|c|c|c|}
\hline الدلالة & قيمة ت & الانحيراف & الحستوسط & العد العد & الجنس & 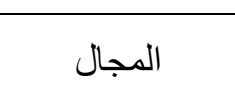 \\
\hline \multirow{2}{*}{0.507} & \multirow{2}{*}{0.67} & 0.55 & 3.82 & 15 & ذكر & \multirow[t]{2}{*}{ الأهداف } \\
\hline & & 0.53 & 3.69 & 20 & أنثى & \\
\hline \multirow{2}{*}{0.259} & \multirow{2}{*}{1.14} & 0.62 & 3.76 & 15 & ذ ذكر & \multirow[t]{2}{*}{ المحتوى } \\
\hline & & 0.40 & 3.56 & 20 & أنثى & \\
\hline \multirow{2}{*}{0.447} & \multirow{2}{*}{0.77} & 0.79 & 3.80 & 15 & ذكر & \multirow{2}{*}{ الوسائل التعليمية } \\
\hline & & 0.48 & 3.64 & 20 & أنثى & \\
\hline \multirow{2}{*}{0.369} & \multirow{2}{*}{0.91} & 0.77 & 4.03 & 15 & ذكر & \multirow{2}{*}{ طر ائق التدريس } \\
\hline & & 0.45 & 3.84 & 20 & أنثى & \\
\hline \multirow{2}{*}{0.358} & \multirow{2}{*}{0.93} & 0.65 & 3.85 & 15 & ذكر & \multirow{2}{*}{ الكلي } \\
\hline & & 0.42 & 3.68 & 20 & أنثى & \\
\hline
\end{tabular}

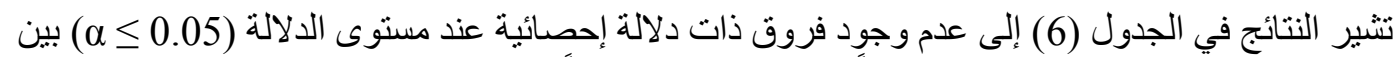

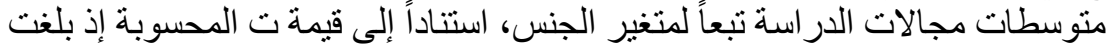

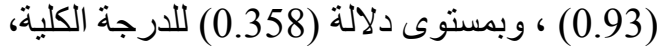

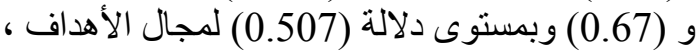

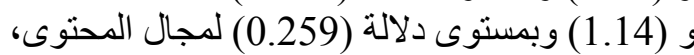

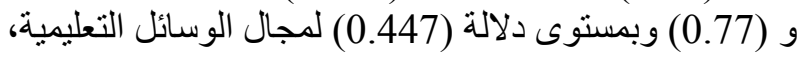

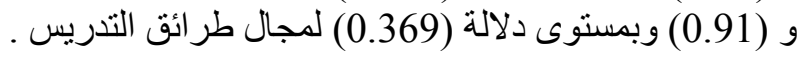




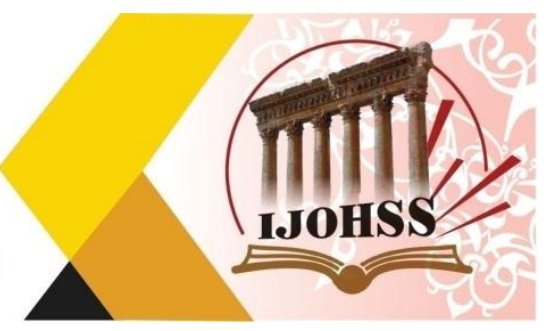

\section{الفصل الخامس \\ التوصيات والمقترحات الخمن}

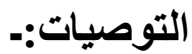

توصي الباحثة

1- اعتماد النتائج التي توصل إليها البحث الحالي من قبل وزارة التربية و التعليم في تعديل المنهج

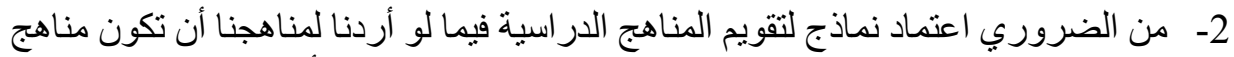

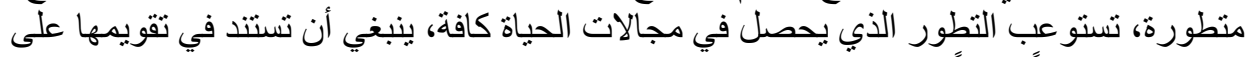
نماذج مبنية بناءاً علمياً.

1- القيام بدر اسات مماثلة للمر احل الدراسية الأخرى من التعليم العام.

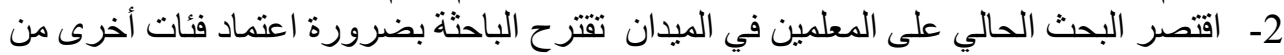

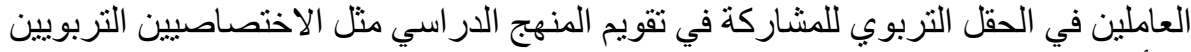

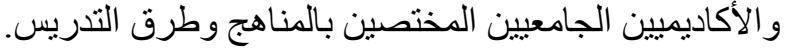

1- أسصاليب التقويم و القياس،1989،أحمد ذيبان غزاوي ، المركز العربي لتطوير الأطر التدريسية والتدريبية في

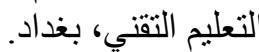

2- الاتجاهات في التخطيط و التطويرمناهج المرحلة الأولى،1988،حلمي أحمد وحسين بشير محمود الوكيل ،

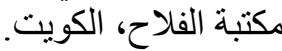
3- المناهج، 1972، سرحان ومنيو كامل الدمرداش ،دار العلوم للطباعة و النشر، القاهرة.

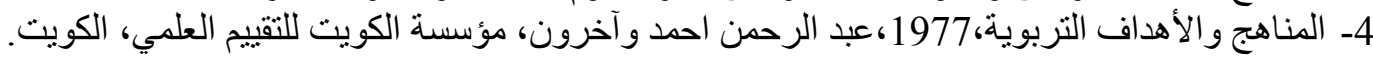
5- المناهج ونطبيقاته التربوية،1990، مجيد مهدي الاهية محمد ، وزارة التعليم العالي والبحث العلمي، جامعة الكية

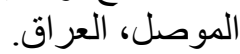

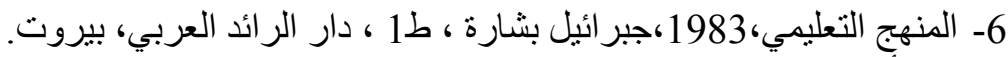

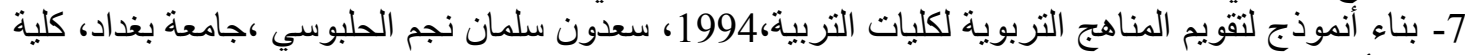

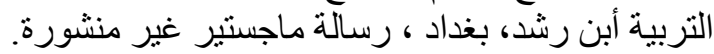

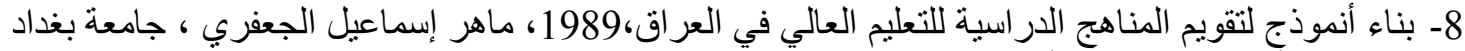

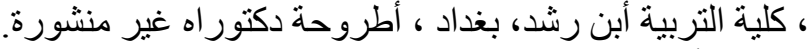

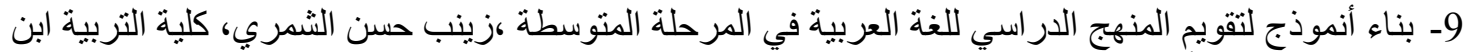

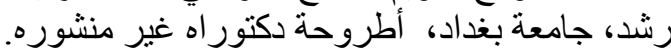

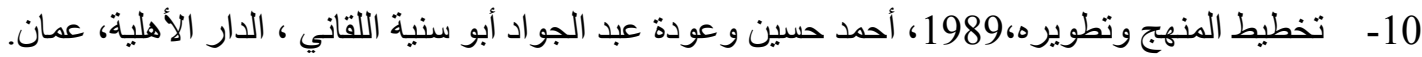

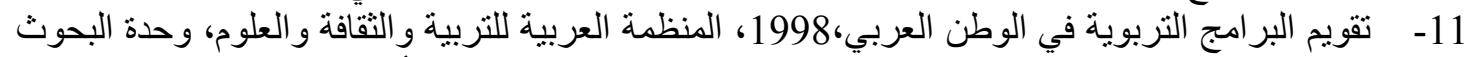

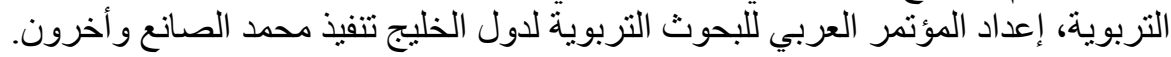

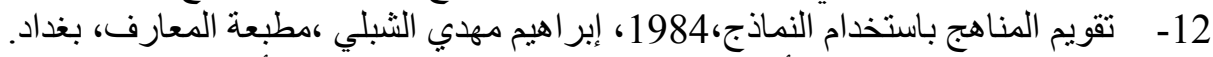

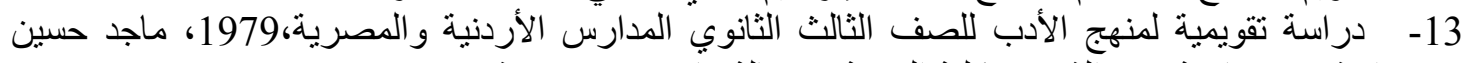

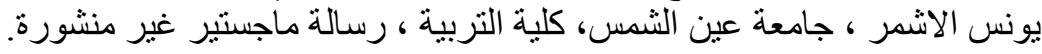

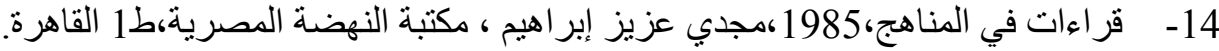
15- مناهج البحث في التربية وعلم النفس،1996،جابر عبد الحميد جابر ، دار النهضة العربية، القاهرة. 

International Journal on Humanities and Social Sciences website:www.ijohss.com

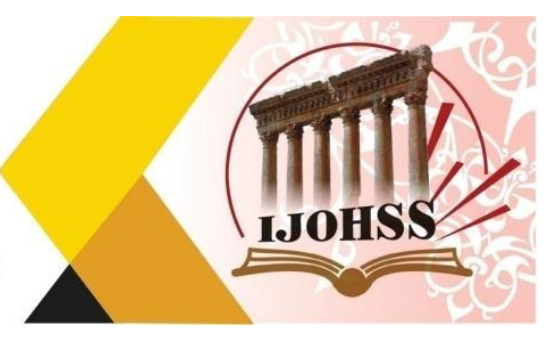

$$
\text { أنموذج التقويم المستخدم في البحث الرحمث الرحمث }
$$$$
\text { السادة المعلمين و المعلمات الأفاضل }
$$$$
\text { بعد التحية والاحتر ام ل... }
$$

في النية تقويم المناهج التربوية الحديثة للتعليم العام في العر اق وفق أنموذج الجعفري2011 المعدل، والذي

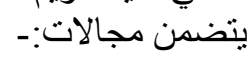

$$
\begin{aligned}
& \text { 1- أهداف المنهج الدر اسي لمادة التربية الإسلامية. } \\
& \text { 2- 2- - محتوى الكتب الدر اسية. } \\
& \text { 3- - طر ائق التدريس. }
\end{aligned}
$$

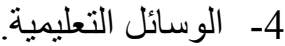

$$
\begin{aligned}
& \text { أرجو التفضل باستجاباتكم العلمية و الموضو عية على فقرات الأنموذج . }
\end{aligned}
$$$$
\text { ولكم فائق التقدير و الاحتر ام الأن }
$$

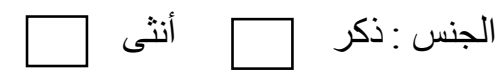




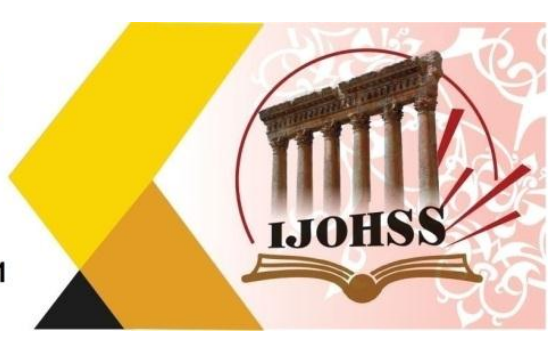

\begin{tabular}{|c|c|c|c|c|c|c|}
\hline لأواً & إلافق & إلى ما & موافق & جواً & مدى تحقق مجال أهداف المواد الاراسية ومفرداتها & $ت$ \\
\hline & & & & & 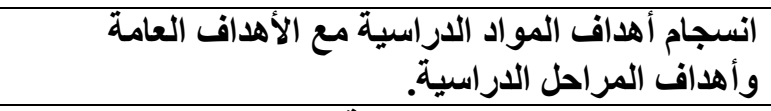 & 1 \\
\hline & & & & & مراعاة مفردات المواد الدراسية لمبادئ نظريات التعلم. & 2 \\
\hline & & & & & قدرة المفردات على تجسيد أهداف المواد الدراسية. & 3 \\
\hline & & & & & دقة أهداف المفردات ووضوحها. & 4 \\
\hline & & & & & تكامل مفردات المواد الدراسية فيما بينها. & 5 \\
\hline & & & & & واستعبداداتهرد. & 6 \\
\hline & & & & & والإبداع. & 7 \\
\hline & & & & & قرتتها الكشف عن مواهب الطلبة و هو اياتهم وتنميتها. & 8 \\
\hline & & & & & إمكان ترجمة المفردات إلى خبرات ونشاطات تعليمية. & 9 \\
\hline & & & & & قالمرحلة الدراسية. تحقيق الأهداف التريوية العامة وأهداف & $\mathbf{1 0}$ \\
\hline & & & & & واقعية أهداف المواد الدراسية وإمكان تطبيقا. & 11 \\
\hline & & & & & بين الطلاب. أهداف المواد الدراسية ومفرداتها الفروق الفردية & 12 \\
\hline & & & & & ملائمة أهداف المواد الدراسية ومفرداتها لأسس النمو & 13 \\
\hline & & & & & ارتباطُ أهداف المواد الدراسية بأهداف المرحلة. & 14 \\
\hline & & & & & انسجام أهداف المواد الدراسية فيما بينها. & 15 \\
\hline & & & & & أغظاء مفردات المواد بالجوانب العملية فضلا عن الجوانب & 16 \\
\hline & & & & & تلارج أهداف المواد الدراسية في كل صف وانسجامها مع & 17 \\
\hline & & & & & تكامل أهداف المواد الدراسية للصف الواحذ. & 18 \\
\hline & & & & & ارتباط أهداف المواد الدراسية للصف الواحد. & 19 \\
\hline & & & & & التوازن بين مفردات فصول المادة الدراسية. & 20 \\
\hline & & & & & قدرة أهداف المواد الدراسية ومفرداتها على نمو التفكير. & 21 \\
\hline & & & & & قدرتها على محاكاة الواقع المحيط بالطلبة. & 22 \\
\hline
\end{tabular}


المجلة الحولية اللملوم الأسانية والإمتصاعية International Journal on Humanities and Social Sciences website:www.ijohss.com

Email:editor@ijohss.com

العدد (28) ديسمبر 2021

ISSN: $2415-4822$

Volume (28) December 2021

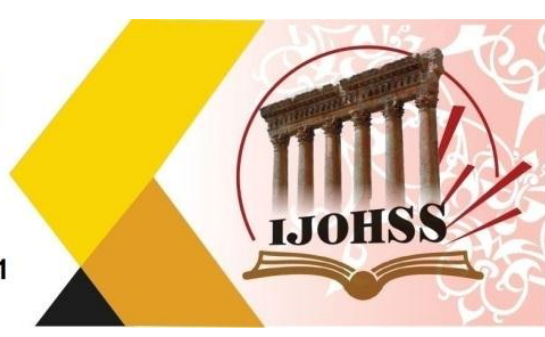

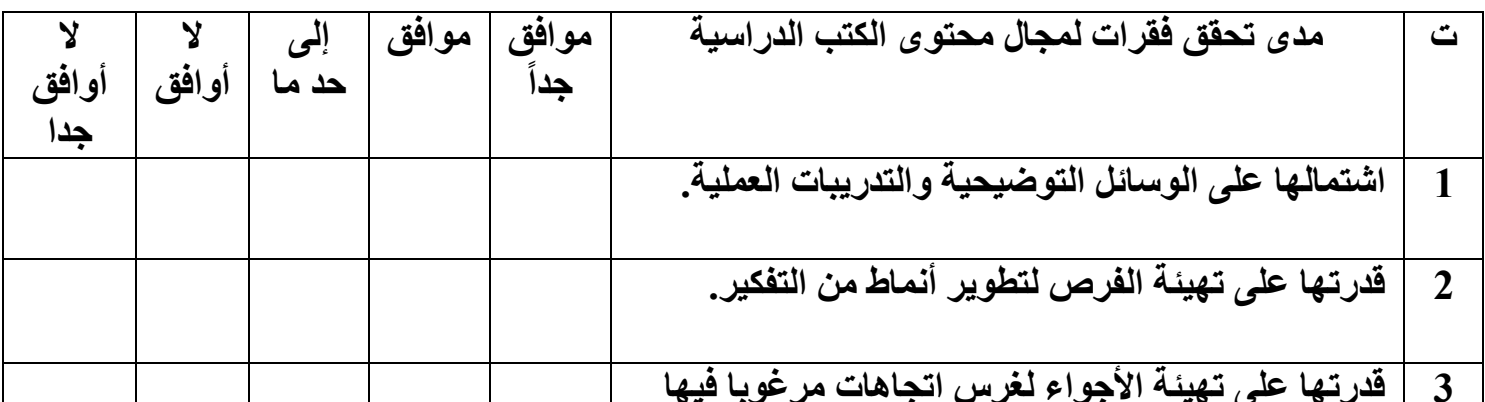

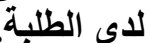

\begin{tabular}{|l|l|l|c|}
\hline & & & \\
\hline
\end{tabular}

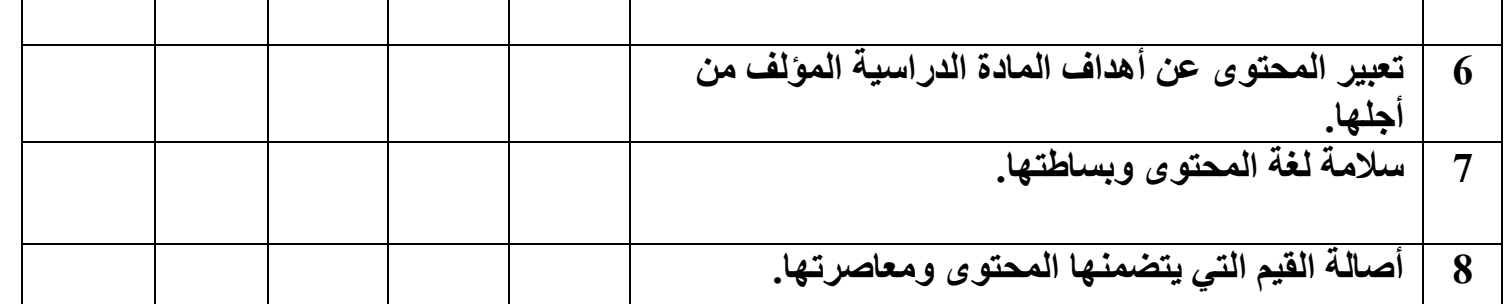

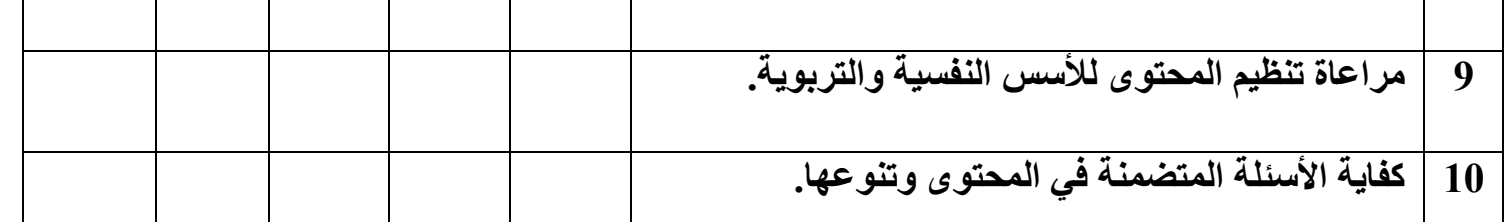

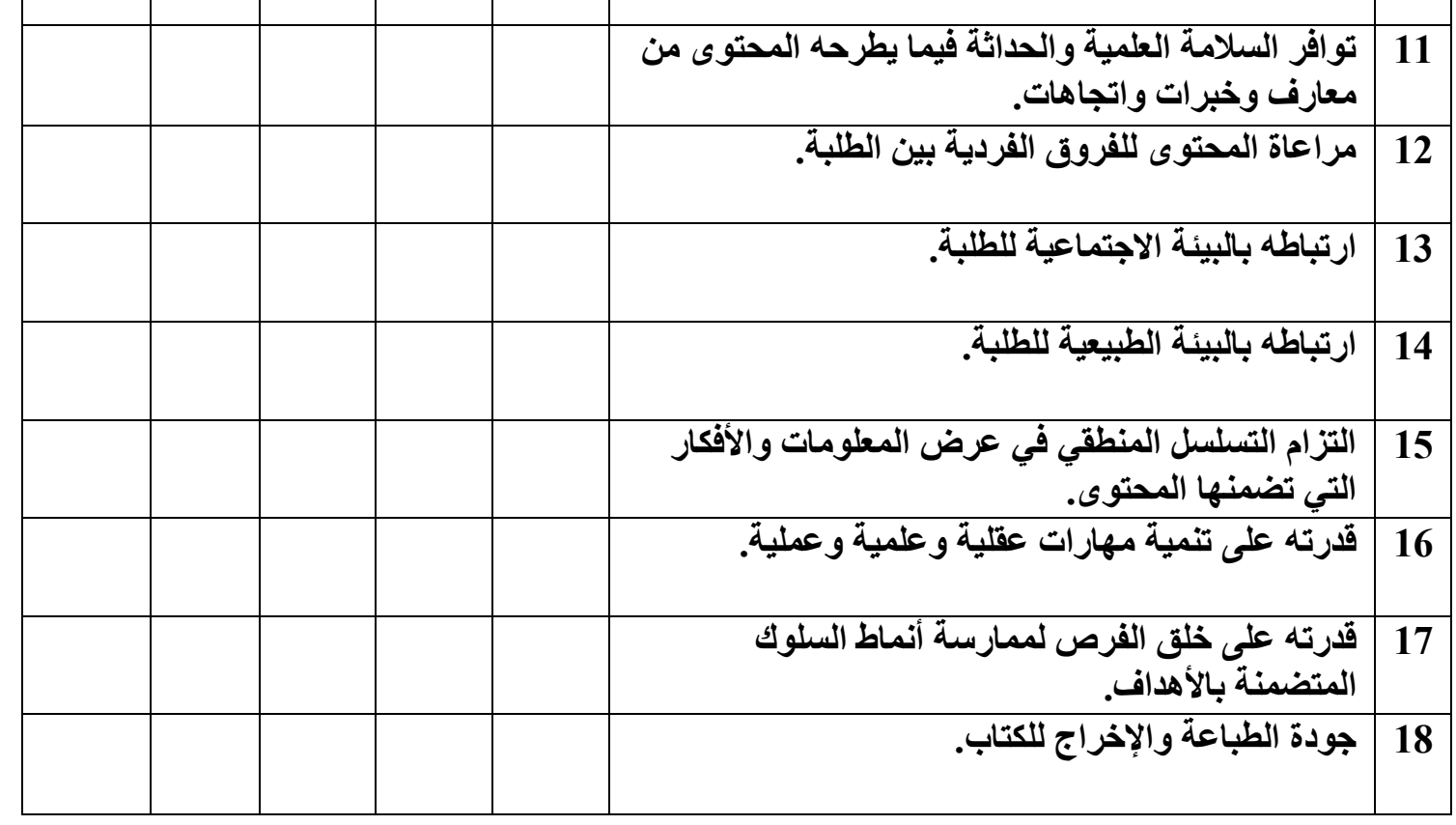


المجلة الحولية اللهلور الأسانية والإمتماعية International Journal on Humanities and Social Sciences website:www.ijohss.com Email:editor@ijohss.com ISSN: 2415 - 4822

العدد (28) ديسمبر 2021

Volume (28) December 2021

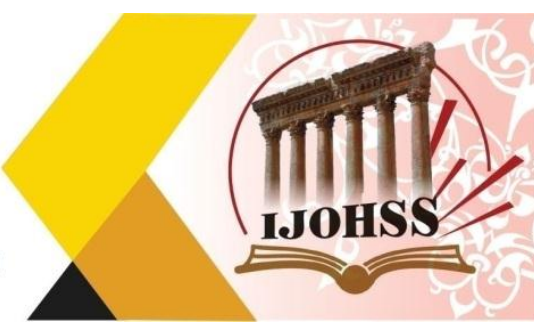

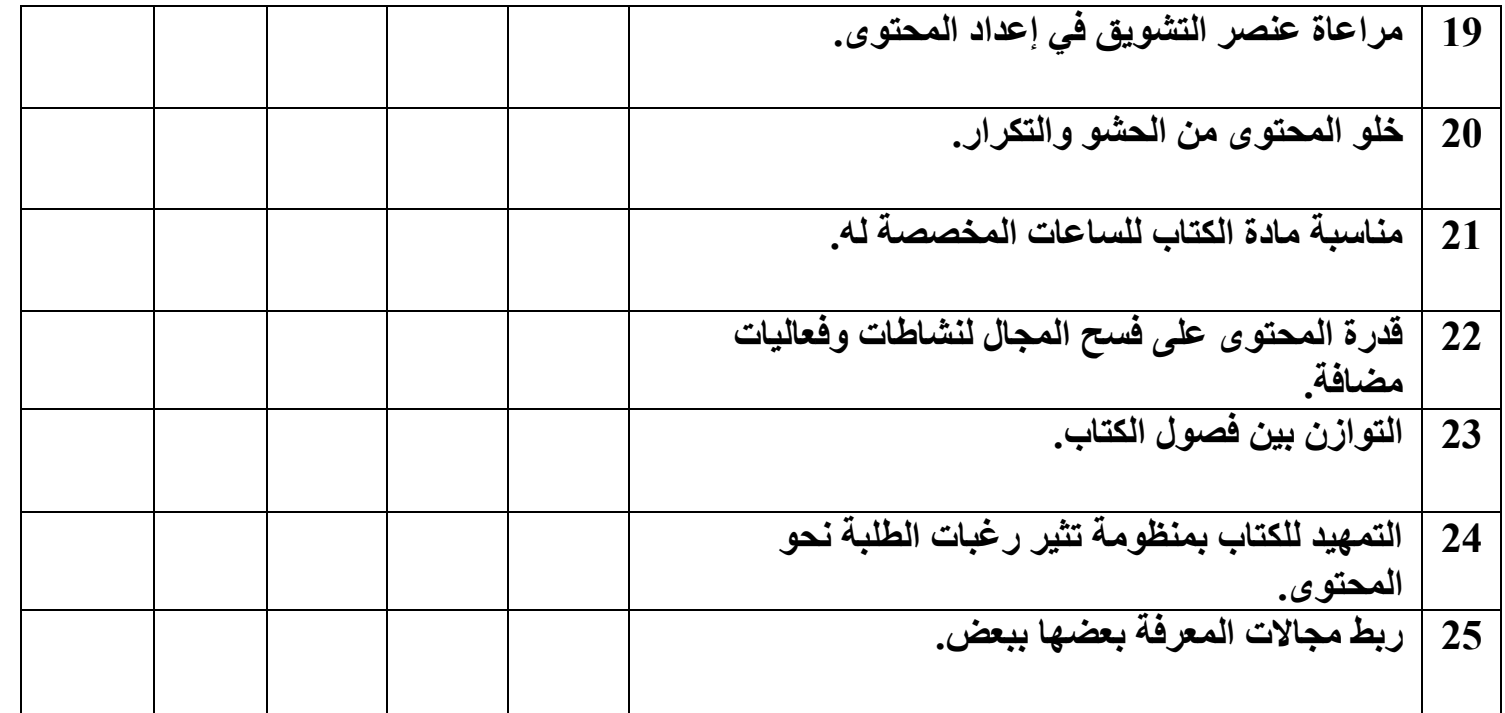


المبلة اللحولية اللملوم الآسانية والامتماعية International Journal on Humanities and Social Sciences website:www.ijohss.com

Email:editor@ijohss.com

العدد (28) ديسمبر 2021

ISSN: $2415-4822$

Volume (28) December 2021

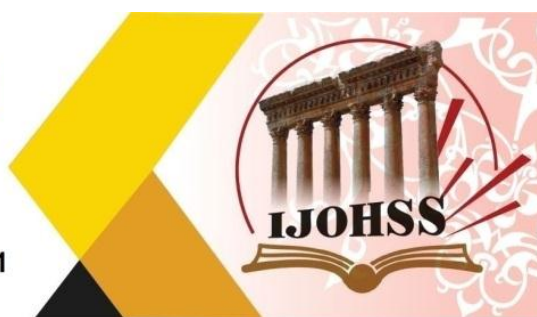

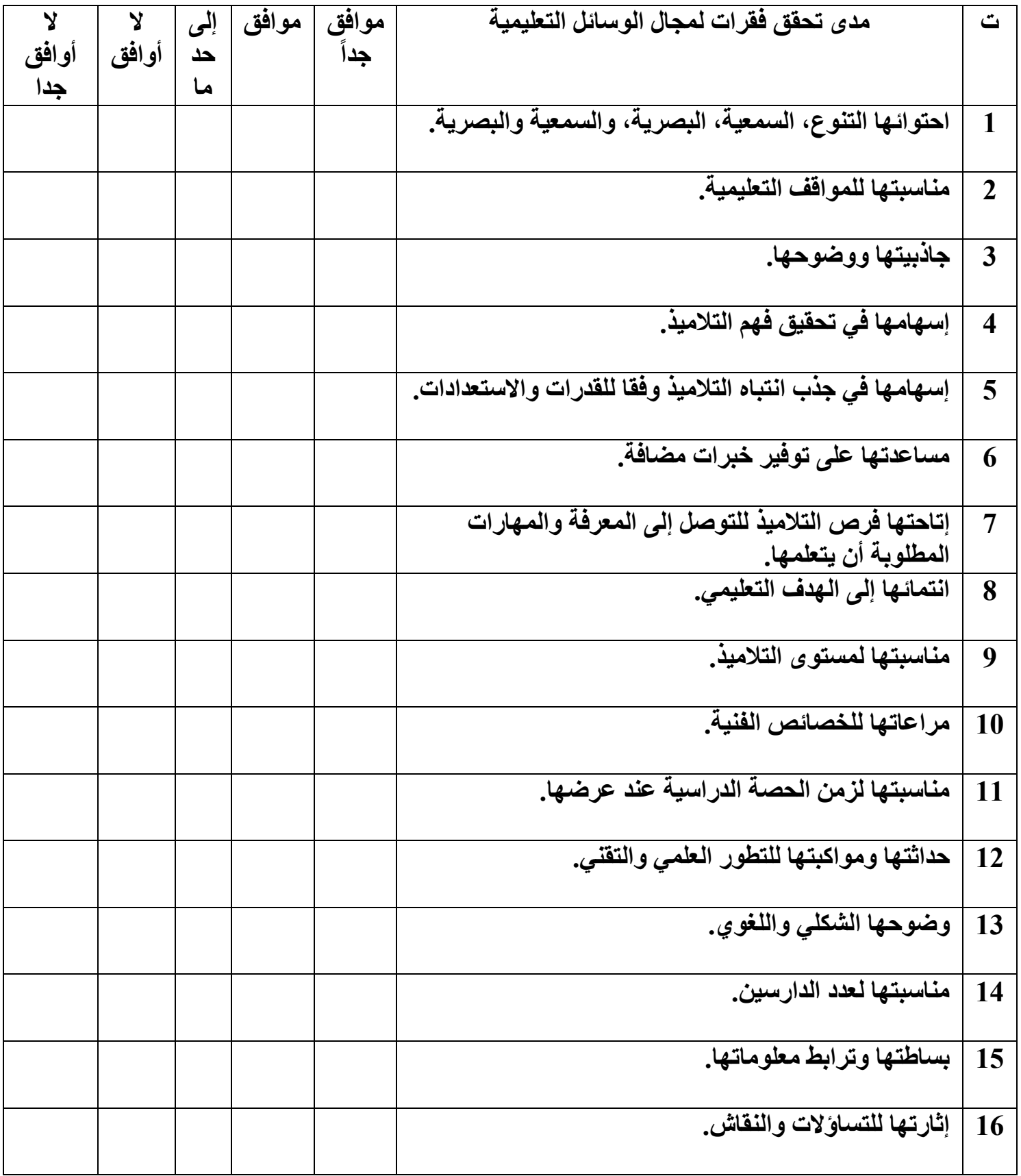


المجلة الحولية اللملوم الأسانية والإمتصاعية International Journal on Humanities and Social Sciences website:www.ijohss.com

Email:editor@ijohss.com

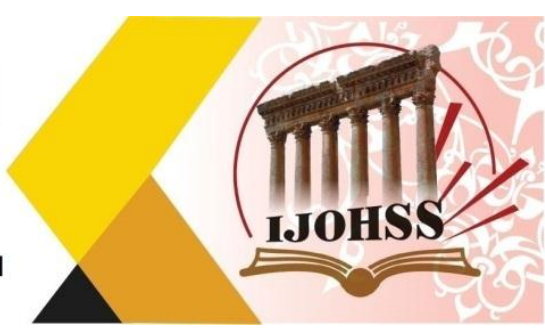

\begin{tabular}{|c|c|c|c|c|c|c|}
\hline لا أوافق & لا لأوافق & 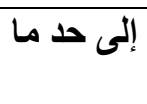 & 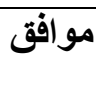 & موافً & مدى تحقق فقرات طرائق التدريس & $ت$ \\
\hline & & & & & إمكانيتها في تحقيق الأهداف التعليمية. & 1 \\
\hline & & & & & مر اعاتها لمستوى الطلبة (النفسي والجسمي والاجتماعي). & 2 \\
\hline & & & & & مناسبتها لطبيعة المادة الدراسية"الموضوع الدراسي". & 3 \\
\hline & & & & & مر اعاتها للفروق الفردية بين الطلبة. & 4 \\
\hline & & & & & قارتها على إثارة اهتمام المتعلم ودافعيته الايجابية. & 5 \\
\hline & & & & & إتاحتها فرص المشاركة الفاعلة للطلبة. & 6 \\
\hline & & & & & تمكنها من توظيف الموضوع الدراسي وربطها بحياة الطلبة وخبراتهم. & 7 \\
\hline & & & & & إتاحتها فرص العمل الجماعي التعاوني على أسس ديمقراطية. & 8 \\
\hline & & & & & قرتها على تنمية الثجاعة الفكرية عند الطلبة. & 9 \\
\hline & & & & & قارتها على إثارة السؤال والتساؤل والتعبير عن الرأي. & $\mathbf{1 0}$ \\
\hline & & & & & مناسبتها للمرحلة التعليمية. & 11 \\
\hline & & & & & تنوعها وفق الموضوع الدراسي. & 12 \\
\hline & & & & & مناسبتها لعدد طلاب الصف. & 13 \\
\hline & & & & & توافقها مع أغراض التعليم داخل الصف وخارجه. & 14 \\
\hline & & & & & مناسبتها لإمكانات المدرسة. & 15 \\
\hline & & & & & إمكانيتها في تحقيق الأهداف التعليمية. & 16 \\
\hline
\end{tabular}

